\title{
Sexual risk behaviors and HIV risk among Americans aged 50 years or older: a review
}

This article was published in the following Dove Press journal:

Substance Abuse and Rehabilitation

2I April 2015

Number of times this article has been viewed

\author{
Daniel J Pilowsky ${ }^{1,2}$ \\ Li-Tzy $\mathrm{Wu}^{3,4}$ \\ 'Columbia University Medical \\ Center, Department of Epidemiology, \\ Mailman School of Public Health \\ New York City, NY, USA; ${ }^{2}$ Division \\ of Epidemiology, New York State \\ Psychiatric Institute, New York City, \\ NY, USA; ${ }^{3}$ Department of Psychiatry \\ and Behavioral Sciences, School of \\ Medicine, ${ }^{4}$ Center for Child and \\ Family Policy, Duke University, \\ Durham, NC, USA
}

\begin{abstract}
Although HIV-related sexual risk behaviors have been studied extensively in adolescents and young adults, there is limited information about these behaviors among older Americans, which make up a growing segment of the US population and an understudied population. This review of the literature dealing with sexual behaviors that increase the risk of becoming HIV-infected found a low prevalence of condom use among older adults, even when not in a long-term relationship with a single partner. A seminal study by Schick et al published in 2010 reported that the prevalence of condom use at last intercourse was highest among those aged $50-59$ years $(24.3 \%$; 95\% confidence interval, $15.6-35.8)$ and declined with age, with a $17.1 \%$ prevalence among those aged 60-69 years (17.1\%; 95\% confidence interval, 7.3-34.2). Studies have shown that older Americans may underestimate their risk of becoming HIV-infected. Substance use also increases the risk for sexual risk behaviors, and studies have indicated that the prevalence of substance use among older adults has increased in the past decade. As is the case with younger adults, the prevalence of HIV infections is elevated among ethnic minorities, drug users (eg, injection drug users), and men who have sex with men. When infected, older adults are likely to be diagnosed with HIV-related medical disorders later in the course of illness compared with their younger counterparts. Physicians are less likely to discuss sexual risk behaviors with older adults and to test them for HIV compared with younger adults. Thus, it is important to educate clinicians about sexual risk behaviors in the older age group and to design preventive interventions specifically designed for older adults.
\end{abstract}

Keywords: HIV/AIDS, older adults, aging, sexual risk behaviors, condom use

\section{Introduction}

The literature dealing with HIV-related sexual risk behaviors in US populations has focused predominantly on adolescents and young adults. However, American adults are living longer and healthier lives, and many spend greater portions of their lives as sexually active individuals. ${ }^{1}$ In 2013 , an estimated 4.2 million people aged 50 years and older were HIV-infected according to UNAIDS 2013 HIV estimates. ${ }^{2}$ The aim of this review is to provide an update of the literature dealing with sexual risk behaviors of Americans aged 50 years or older to inform research and prevention efforts targeting this population. Although we refer to Americans aged 50 years or older in the title of this article, there are a variety of definitions of older adults in the literature, with some studies focusing on older (eg, aged 65 years or older) and others focusing on younger (eg, aged 50 years or older) cohorts. This review is limited to research published in the last 10 years (2004-2014).

Sexual problems in older adults may be understood as the outcome of a complex system of biological, psychological, and cultural factors. ${ }^{3}$ Although sexual activity declines
Correspondence: Daniel J Pilowsky Epidemiology, Mailman School of Public Health, 722 West 168th Street, New York, NY 10032, USA

EmaildpI4@columbia.edu 
with age, a substantial proportion of older Americans remain sexually active after age 65 years. ${ }^{4}$ According to a survey of a probability sample of 3,005 US adults aged 57-85 years, $83.7 \%, 67.0 \%$, and $38.5 \%$ of men aged $57-64,65-74$, and $75-85$ years, respectively; and $61.6 \%, 39.5 \%$, and $16.7 \%$ of women aged 57-64, 65-74, and 75-85 years, respectively, reported sexual activity with a partner in the previous 12 months. ${ }^{4}$ In this survey, women were less likely to have a spouse or intimate partner than men (eg, among those aged $75-85$ years, $78 \%$ and $40 \%$ of men and women, respectively, reported having a spousal or other intimate relationship). Several factors may explain this sex discrepancy, including age differentials (on average, men are married to younger women), differential remarriage patterns, the shorter lifespan of men compared with women, ${ }^{4}$ and a differential level of interest (eg, older men are more likely to remain interested and to engage in sexual activity than older women). ${ }^{5}$ The US Centers for Disease Control and Prevention (CDC) estimates that in 2011, there were 3,951 new HIV cases in the United States among adults aged 50-54 years, 2,312 cases among those aged 55-59 years, 1,229 cases among those aged 60-64 years, and 948 cases among those aged 65 years and older (Figure 1).6,7

As shown in Table 1, reproduced from data provided by the $\mathrm{CDC},{ }^{8}$ rates of diagnoses of new HIV infections (per 100,000 among US adults aged 50 years and older) in 2010 were highest among blacks/African Americans (41.6) and lowest among Asians (2.6), with other races/ ethnicities having rates ranging from 3.1 (Native Hawaiian/
Pacific Islander) to 15.4 (Hispanic/Latino) compared with 3.9 among whites.

Some studies suggest that older Americans are more likely to receive a late HIV diagnosis compared with their younger counterparts, ${ }^{9}$ and the same pattern has been noted in the United Kingdom, ${ }^{10}$ thus limiting their exposure to early treatment and increasing the likelihood of greater morbidity. Thus, the United States faces an important public health problem, including a rising number of older HIV-infected adults and an increasing number of HIV infections among some older population groups, such as blacks, Hispanics, recreational drug users, and men who have sex with men (MSM). Further, older men may remain sexually active longer, using erectile dysfunction medications. A study indicated that $17 \%$ of men aged 50 years or older used erectile medication during their most recent sexual event. ${ }^{1}$

\section{Methods}

The following terms were used to search the literature using Ovid MEDLINE ${ }^{\circledR}$ (a software package we used because it is available to Columbia University faculty and students and is also available in many US universities; Figure 2): "Unsafe Sex" and "All Aged (65 and older)." The latter term was used because it is included in the software package, but this search term does not exclude publications focusing on various age ranges (eg, "50 or older" or "55 or older"), as long as those aged 65 years and older are included. In addition to using the terms mentioned here, we used the following inclusion criteria: published in English and published in the last

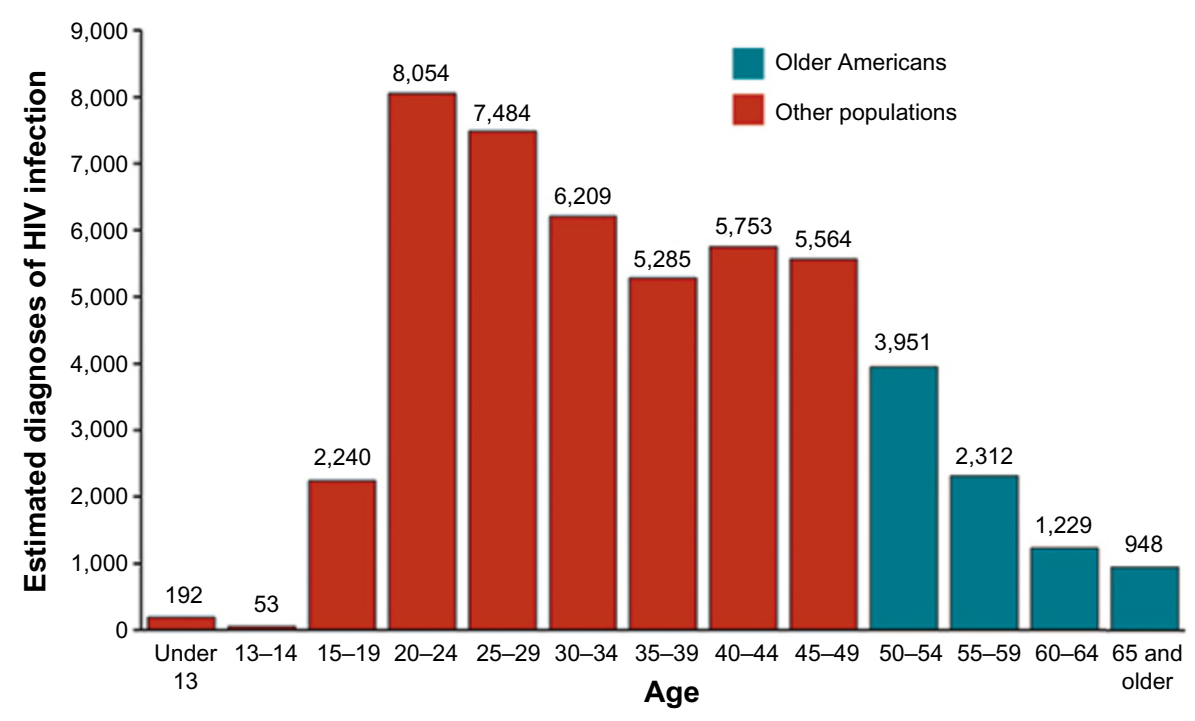

Figure I Estimated diagnoses of HIV infection, by age, 20 I I, United States.

Note: Figure reproduced from Centers for Disease Control and Prevention. Centers for Disease Control and Prevention. HIV among older Americans. Atlanta, GA: Centers for Disease Control and Prevention; 2013. Available from: http://www.cdc.gov/hiv/pdf/library_factsheet_HIV_\%20AmongOlderAmericans.pdf. Accessed April I0, 20I5. ${ }^{7}$ 
Table I Diagnoses of HIV infection among adults aged 50 years and older by age at diagnosis (years) and race ethnicity

\begin{tabular}{|c|c|c|c|c|c|c|c|c|c|c|c|c|}
\hline \multirow[t]{3}{*}{ Characteristic } & \multicolumn{3}{|l|}{2007} & \multicolumn{3}{|l|}{2008} & \multicolumn{3}{|l|}{2009} & \multicolumn{3}{|l|}{2010} \\
\hline & \multirow[t]{2}{*}{ No } & \multicolumn{2}{|c|}{ Estimated* } & \multirow[t]{2}{*}{ No } & \multicolumn{2}{|c|}{ Estimated* } & \multirow[t]{2}{*}{ No } & \multicolumn{2}{|c|}{ Estimated* } & \multirow[t]{2}{*}{ No } & \multicolumn{2}{|c|}{ Estimated* } \\
\hline & & No & Rate $^{\#}$ & & No & Rate $^{\#}$ & & No & Rate $^{\#}$ & & No & Rate $^{\#}$ \\
\hline \multicolumn{13}{|l|}{ Age at diagnosis, years } \\
\hline $50-54$ & 3,583 & 3,708 & 18.6 & 3,372 & 3,558 & 17.5 & 3,276 & 3,568 & 17.3 & 3,124 & 3,671 & 17.8 \\
\hline $55-59$ & 1,996 & 2,062 & 11.9 & 1,998 & 2,106 & 12.0 & 1,924 & 2,091 & 11.6 & 1,825 & 2,154 & 12.0 \\
\hline $60-64$ & 952 & 982 & 7.2 & 991 & $\mathrm{I}, 040$ & 7.3 & 890 & 961 & 6.4 & 945 & 1,119 & 7.5 \\
\hline $65-69$ & 502 & 519 & 5.1 & 479 & 508 & 4.7 & 425 & 462 & 4.1 & 437 & 522 & 4.7 \\
\hline $70-74$ & 205 & 212 & 2.6 & 173 & $|8|$ & 2.2 & 193 & 210 & 2.5 & 171 & 199 & 2.3 \\
\hline $75-79$ & 97 & 100 & 1.4 & 86 & 90 & 1.3 & 83 & 90 & 1.3 & 74 & 90 & 1.3 \\
\hline $80-84$ & 27 & 28 & 0.5 & 25 & 26 & 0.5 & 28 & 30 & 0.5 & 28 & 33 & 0.6 \\
\hline$\geq 85$ & 9 & 9 & 0.2 & 11 & 12 & 0.2 & 3 & 4 & 0.1 & 8 & 9 & 0.2 \\
\hline \multicolumn{13}{|l|}{ Race/ethnicity } \\
\hline $\begin{array}{l}\text { American Indian/ } \\
\text { Alaska Native }\end{array}$ & 30 & 31 & 5.8 & 34 & 35 & 6.4 & 24 & 25 & 4.4 & 30 & 34 & 5.9 \\
\hline Asian & 79 & 82 & 2.8 & 71 & 74 & 2.4 & 72 & 80 & 2.5 & 70 & 85 & 2.6 \\
\hline Black/African American & 3,426 & 3,542 & 43.6 & 3,503 & 3,696 & 44.0 & 3,244 & 3,519 & 40.6 & 3,056 & 3,605 & 41.6 \\
\hline Hispanic/Latino ${ }^{\ddagger}$ & $\mathrm{I}, 154$ & 1,200 & 17.0 & 989 & 1,052 & 14.1 & 1,036 & $1,|14|$ & 14.5 & 1,008 & 1,212 & 15.4 \\
\hline Native Hawaiian/other & 11 & 11 & 18.8 & 6 & 6 & 9.6 & 9 & 9 & 13.8 & 2 & 2 & 3.1 \\
\hline \multicolumn{13}{|l|}{ Pacific Islander } \\
\hline White & 2,547 & 2,625 & 3.9 & 2,418 & 2,536 & 3.7 & 2,333 & 2,526 & 3.6 & $2,36 I$ & 2,762 & 3.9 \\
\hline Multiple races & 124 & 129 & 22.0 & 114 & 123 & 20.0 & 104 & 115 & 18.0 & 85 & 98 & 15.3 \\
\hline Total $\|^{\pi}$ & 7,371 & 7,620 & 8.8 & 7,135 & 7,523 & 8.4 & 6,822 & 7,415 & 8.1 & 6,612 & 7,797 & 8.5 \\
\hline
\end{tabular}

Notes: *Estimated numbers resulted from statistical adjustment that accounted for reporting delays and missing risk factor information, but not for incomplete reporting; "rates are per 100,000 population; \#Hispanics/Latinos can be of any race. "Because column totals for estimated numbers were calculated independent of the values for the subpopulations, the values in each column may not sum to the column total. Adapted from Table Ia from the Centers for Disease Control and Prevention. Diagnoses of HIV infection among adults aged 50 years and older in the United States and dependent areas, 2007-20I0. HIV Surveillance Supplemental Report 20I3. Atlanta, GA: Centers for Disease Control and Prevention; 2013. Available from: http://www.cdc.gov/hiv/pdf/statistics_20I0_HIV_Surveillance_Report_vol_18_no_3.pdf. Accessed October 27, 20I4. ${ }^{8}$

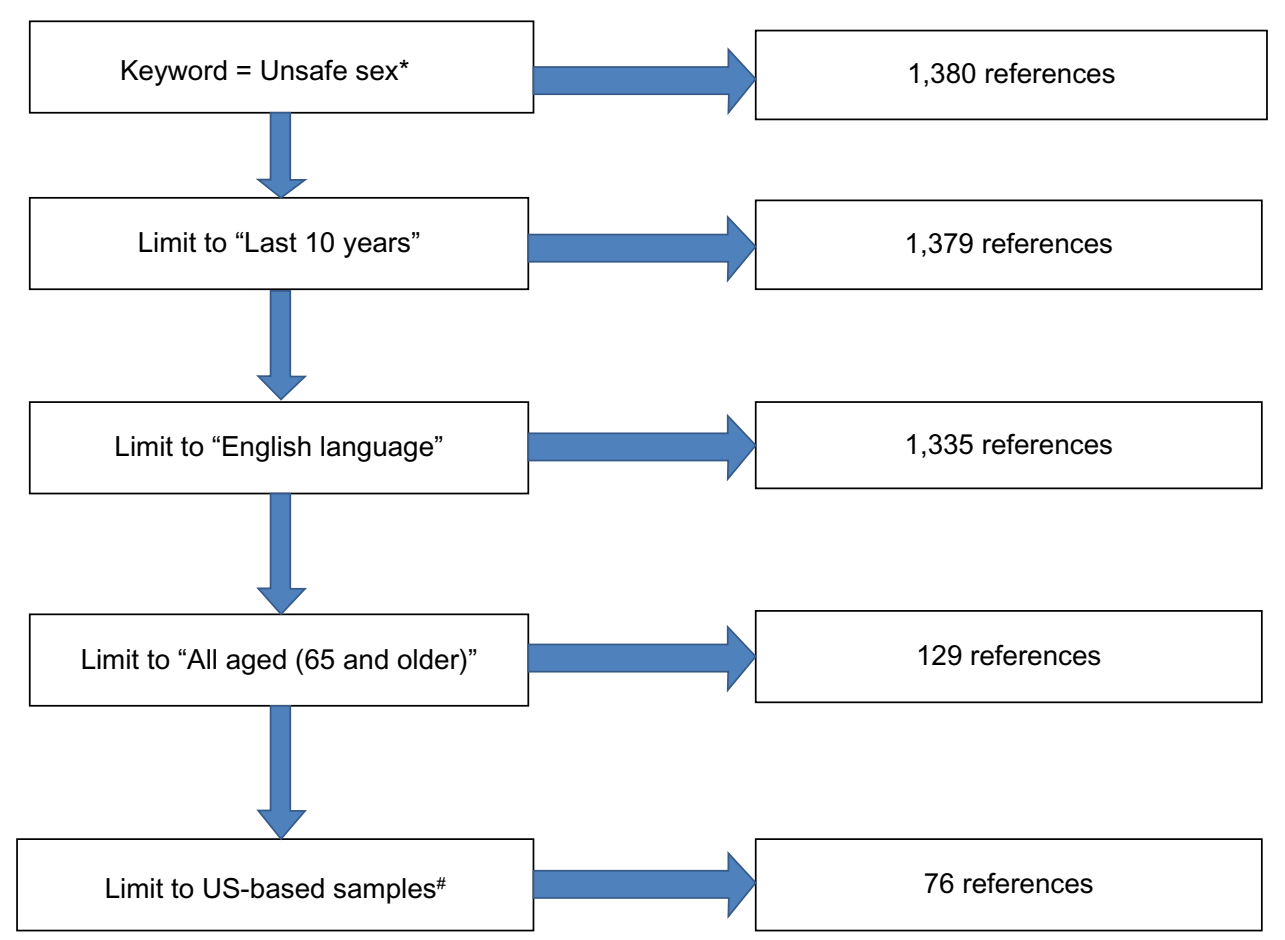

Figure 2 Search strategy.

Notes: Search was performed using Ovid MEDLINE. *Choose "Focus" (rather than "Explode") and choose "Include All Subheadings" (options available in Ovid MEDLINE). "Focus" refers to including most relevant references. "Explode" refers to including references that are only marginally relevant to the topic selected (in addition to those most relevant); " references to studies of non-US populations were excluded manually, leading to the exclusion of 53 references (I29-53=76). Most of the excluded references referred to studies of samples in the People's Republic of China, Brazil, and Western Europe. 
10 years. Finally, we manually excluded publications focusing on non-US samples. The search strategy is described in detail in Figure 2. With the exception of the manual exclusion of publications focusing on non-US samples, the search strategy is reproducible by readers with access to Ovid MEDLINE ${ }^{\circledR}$ and other software packages that use similar search terms. Among the 1,335 papers dealing with unsafe sex and published in English in the last 10 years, only 129 focused on older individuals; of them, 76 focused on studies of older American adults. Because more than half of these papers dealt marginally, if at all, with sexual risk behaviors among older American adults, references from these papers were selectively explored, leading to the review of additional publications, including a few published more than 10 years ago.

\section{Results}

We present results of the literature review focusing on five distinct themes: sex, ethnicity, and health status as they relate to the risk of becoming HIV-infected among older adults; sexual behavior of older adults with emphasis on condom use because of the pivotal role of condom use in the prevention of HIV infections; sexual risk behaviors of older American women; sexual risk behaviors of older MSM, also discussed separately because of the high incidence of HIV/AIDS among MSM; substance use/abuse among older adults, with special attention to the association with high-risk sexual behaviors; and HIV-infected older adults.

To provide context, we also discuss the correlates of highrisk sexual behaviors in the general population (ie, regardless of age). Prominent among these correlates is race/ethnicity. Estimates of HIV prevalence have shown that blacks are overrepresented among HIV-positive Americans in general and among MSM in particular, and this is true among older Americans as well. ${ }^{11-14}$ Sex and sexual orientation are also associated with HIV acquisition, with a high prevalence in the United States among males in general and MSM in particular. ${ }^{12,14}$

\section{Sex, ethnicity, and health}

The distribution of prevalent HIV-infected cases in the United States is skewed, with males accounting for $80 \%$ of incident cases in $2010 .{ }^{15} \mathrm{MSM}$ are at increased risk of becoming HIV-infected compared with the general US population. ${ }^{13,15}$ There are large ethnic disparities in HIV incidence and prevalence in the United States. For example, according to the CDC, the rates of HIV infection (per 100,000 population) in 2012 were 58.3 for blacks/African Americans, 18.5 for Hispanics/Latinos, 17.3 for persons of multiple races, and 6.7 for whites. ${ }^{16}$ Similar patterns in sex and racial/ethnic disparities have been reported among older Americans. ${ }^{13}$

There are striking differences in HIV transmission categories between males and females (Figure 3). ${ }^{6,7}$ According to a CDC analysis of transmission routes among older Americans, the vast majority of females $(82 \%)$ and a smaller proportion of males $(23 \%)$ became infected through heterosexual contact in 2010. Male-to-male sexual contact accounted for more than half of the infections (60\%) among men. As shown in Figure 3, most of the remaining cases were related to injection drug use.

Health appears to have a complex relation to the risk of becoming HIV-infected and to disease progression among those infected. Using self-reported general population data (limited to adults aged 50 years or older), Schick et al classified individuals' health status as "good" or "poor."1 Compared with those in good health, older Americans in poor health appear more likely to engage in solo masturbation and frottage sexual practices not associated with an elevated risk of becoming HIV-infected. However, among those HIV-infected, poor health complicates the treatment of older adults. As they age, HIV-infected adults are likely to be affected by illnesses that are common among older US adults in the general population, but these illnesses seem to be more prevalent among those HIV-infected than is expected for their age. ${ }^{17}$ These disorders may include cardiovascular, renal, and hepatic illnesses, osteopenia, and endocrine and metabolic abnormalities, which in turn may further affect their prognosis. ${ }^{18,19}$ For example, an increasing number of older HIV-infected persons have non-AIDS-defining cancers, such as anal, lung, colorectal, and liver cancers, leading some to conclude that the strongest, but not the sole, epidemiological predictor of non-AIDS-defining cancers is age.$^{20}$ Brooks et al have identified three sets of factors that contribute to heightened risk for disease progression in this age group: ${ }^{17}$ viral replication and attendant inflammation, complications of treatment with protease inhibitors and other antiretroviral agents, and host-related factors such as concurrent infections (eg, hepatitis B) and lifestyle factors (eg, alcohol use and misuse). A detailed examination of the evidence supporting the role of these factors is beyond the scope of this review, but knowing that older Americans living with HIV have a disproportionately high prevalence of coexisting medical disorders is important for planning for the care of this vulnerable group. Older adults are more likely to remain in treatment than their younger counterparts, and 

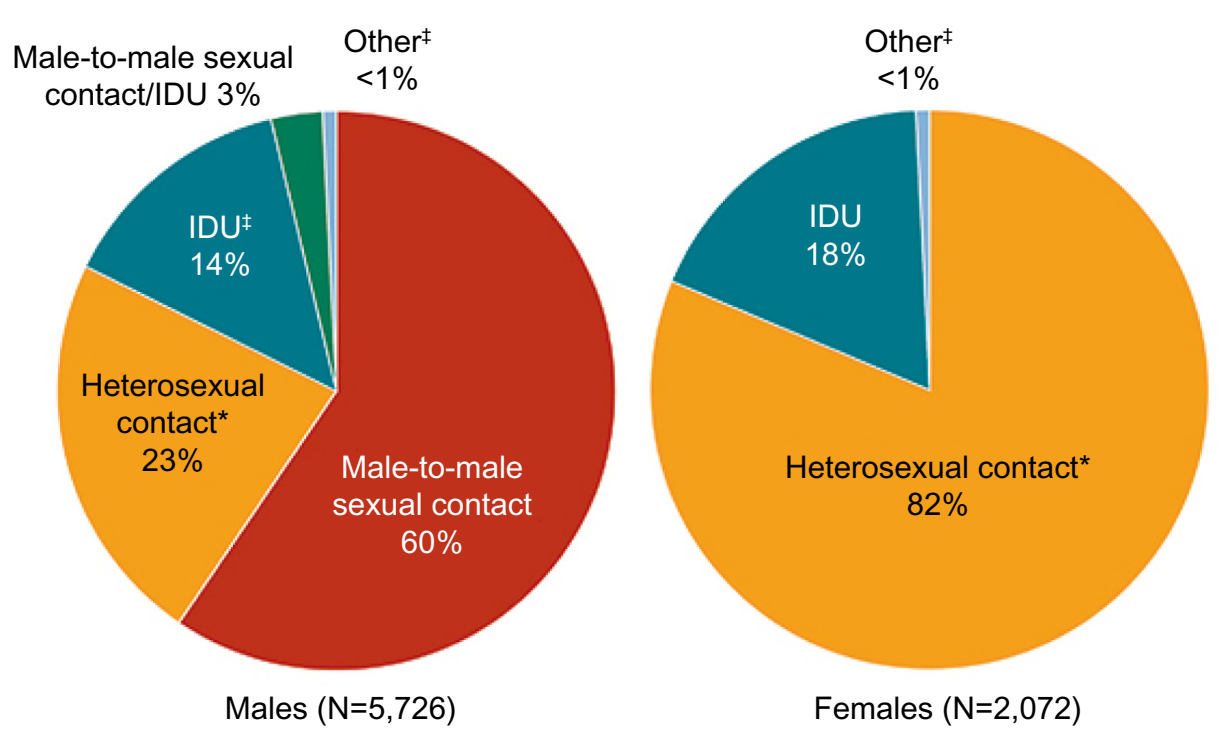

Figure 3 Estimated diagnoses of HIV infection among adults aged 50 and older by sex and transmission category, 20I0, 46 states.

Notes: $¥$ Other transmission risk factors include hemophilia, blood transfusion, and risk factors not reported or identified; *heterosexual contact with a person known to have or be at high risk for, HIV infection. Due to rounding, percentages may not add up to 100\%. Figure reproduced from Centers for Disease Control and Prevention. HIV Among Older Americans. Atlanta, GA: Centers for Disease Control and Prevention; 20I3. Available from: http://www.cdc.gov/hiv/risk/age/olderamericans/. Accessed: October I5, 20I4.73

Abbreviation: IDU, injection drug use.

adherence to antiretroviral therapy is better in older than in younger populations. ${ }^{18,21}$

\section{Sexual behavior and condom use among older adults}

Selected publications dealing with unsafe sexual behaviors among older adults are summarized in Table 2. Using data from the National Survey of Sexual Health and Behavior, Schick et al examined the prevalence of condom use during the last sexual event among Americans aged 50 years or older who met one or more of the following criteria: ${ }^{1}$ reported engaging in penile-vaginal intercourse within the past year, defined their relationship status as single, reported that their most recent sexual partner was not their primary sexual partner, or reported that their current relationship was recent (ie, less than 1 year). In this group (age 50+ years), about $20 \%$ of men and $24 \%$ of women reported condom use during the last sexual event. ${ }^{1}$ The prevalence of condom use at last intercourse was highest among those aged $50-59$ years (24.3\%; 95\% confidence interval, $15.6 \%-35.8 \%)$ and declined with age, with a $17.1 \%$ prevalence among those aged 60-69 years (17.1\%; 95\% confidence interval, 7.3\%-34.2\%). Cooperman et al also reported a high prevalence of unsafe sex among older adults, ${ }^{22}$ although his study was limited to men (Table 2). Older Americans often view HIV-related sexual risk as affecting the young and sexual minority groups, thus underestimating their own risk, ${ }^{23}$ a perception that may be influenced by the way HIV is portrayed in the media. In addition, physicians often do not discuss sexual behavior with older patients. Data from a survey of 3,005 US adults aged $57-85$ years indicated that just $38 \%$ of men and $22 \%$ of women reported having discussed sex with a physician since the age of 50 years. ${ }^{4}$ Furthermore, according to a systematic chart review, physicians are less likely to ask older patients about their sexual history than young adult patients, ${ }^{24}$ perhaps because they perceive older patients to be at low risk for sexually transmitted diseases or because of discomfort.

\section{Sexual risk behaviors of older women}

Although both older men and women may experience partner loss, women older than 50 years are more likely to be single (26.8 vs 41.3\%). ${ }^{1}$ About 1 in 20 single men and women older than 50 years date one or more persons. ${ }^{1}$ Sizable proportions of older American women are starting new relationships and are exposed to new sexual partners. ${ }^{25}$ Thus, they are at risk of becoming HIV-infected through unprotected sex with new sexual partners. Nevertheless, the literature addressing women is relatively sparse, ${ }^{25}$ and many healthcare providers do not view older women as an at-risk group, and therefore are less likely to test them for HIV infection. ${ }^{26}$ The strongest predictor of past HIV testing among older women was recalling that a provider ever recommended HIV testing. ${ }^{27}$

Biologically, male-to-female transmission is more likely than female-to-male transmission of the HIV virus, ${ }^{28}$ thus 
Table 2 Sexual risk behaviors among older Americans

\begin{tabular}{|c|c|c|c|}
\hline Author & opulation & Data source & Main findings \\
\hline $\begin{array}{l}\text { Cooperman } \\
\text { et al, }(2007)^{22}\end{array}$ & $\begin{array}{l}\text { Men aged } \\
49-80 \text { years, } \\
N=624\end{array}$ & $\begin{array}{l}\text { Cross-sectional } \\
\text { survey }\end{array}$ & $\begin{array}{l}\text { In the preceding } 6 \text { months, } 75 \% \text { of men ( } \mathrm{N}=624 \text {, including } 268 \mathrm{HIV} \text {-negative and } \\
356 \text { HIV-positive men) reported sexual activity with one or more partners. Overall, more } \\
\text { than half of respondents reported risky sexual behaviors (multiple partners, inconsistent } \\
\text { condom use, and trading sex for money or drugs). Risky sexual behaviors were more } \\
\text { common among HIV-negative compared with HIV-positive men; for example, } 57 \% \text { of } \\
\text { HIV-positive vs } 18.1 \% \text { of HIV-negative men "always" used condoms }(P<0.0 \mathrm{I}) \text {, although } \\
\text { about } 25 \% \text { of both groups had multiple sexual partners in the preceding } 6 \text { months. }\end{array}$ \\
\hline $\begin{array}{l}\text { Illa et al, } \\
(2008)^{66}\end{array}$ & $\begin{array}{l}\text { Sexually active } \\
\text { HIV-positive adults } \\
\text { aged } 45 \text { years } \\
\text { and older, } \mathrm{N}=210\end{array}$ & $\begin{array}{l}\text { Cross-sectional } \\
\text { survey }\end{array}$ & $\begin{array}{l}\text { Subjects were receiving HIV-related clinical care in Miami, Florida. "Sexually active" was } \\
\text { defined as having engaged in vaginal or anal intercourse in the last I } 2 \text { months. Of the } \\
210 \text { individuals surveyed, I } 25 \text { were men and } 85 \text { were women, respectively. The sample } \\
\text { was largely heterosexual. Almost } 21 \% \text { of participants reported not using condoms } \\
\text { consistently, and } 33 \% \text { had multiple sexual partners during the preceding } 6 \text { months. } \\
\text { Negative mood and perceived HIV stigma were associated with inconsistent condom use. }\end{array}$ \\
\hline $\begin{array}{l}\text { Lovejoy et al, } \\
(2008)^{67}\end{array}$ & $\begin{array}{l}\text { HIV-positive } \\
\text { depressed adults } \\
\text { aged } 50+\text { years, } \\
\mathrm{N}=290\end{array}$ & $\begin{array}{l}\text { Cross-sectional } \\
\text { survey, three } \\
\text { metropolitan } \\
\text { areas }\end{array}$ & $\begin{array}{l}\text { Of the } 290 \text { individuals surveyed, } 62 \% \text { were abstinent (no sexual episodes in the preceding } \\
3 \text { months). Although most men who have sex with men (64\%) and heterosexual women } \\
\text { (79\%) were abstinent, only } 28 \% \text { of heterosexual men were abstinent. Among those not } \\
\text { abstinent, } 53 \% \text { of heterosexual men reported regular condom use compared with } 23 \% \\
\text { and } 13 \% \text { among men who have sex with men and heterosexual women, respectively. }\end{array}$ \\
\hline $\begin{array}{l}\text { Onen et al, } \\
(2010)^{68}\end{array}$ & $\begin{array}{l}\text { HIV-positive } \\
\text { adults receiving } \\
\text { HIV-related clinical } \\
\text { care, } \mathrm{N}=54 \mathrm{I}\end{array}$ & $\begin{array}{l}\text { Cross-sectional } \\
\text { survey }\end{array}$ & $\begin{array}{l}\text { Although reports of any recent sexual activity decreased with age, from } 56.4 \% \text { among } \\
\text { those aged I8-35 years }(\mathrm{N}=\mathrm{I} 65) \text { to } 27.3 \% \text { among older individuals }(\geq 50 \text { years; } \mathrm{N}=128) \\
(P<0.00 \mathrm{I}) \text {, condom use practices did not differ significantly by age, with } 88.0 \% \text { and } 82.4 \% \\
\text { of those aged } 18-35 \text { years and older individuals ( } \geq 50 \text { years), respectively, reporting } \\
\text { condom use at the last sexual episode. }\end{array}$ \\
\hline $\begin{array}{l}\text { Schick et al, } \\
(2010)^{\prime}\end{array}$ & $\begin{array}{l}\text { US men and } \\
\text { women aged } \\
50+\text { years, } \\
\mathrm{N}=1,973\end{array}$ & $\begin{array}{l}\text { National Survey } \\
\text { of Sexual Health } \\
\text { and Behavior, } \\
\text { conducted } \\
\text { in } 2009\end{array}$ & $\begin{array}{l}\text { I. About } 20 \%-30 \% \text { of both men and women remained sexually active well into their } 80 \text { s. } \\
\text { 2. Condom use rates among those who are single and sexually active, having more than } \\
\text { one sexual partner in the last year, were low across age groups and decreased with } \\
\text { age: } 24.3 \% \text { of those aged } 50-59 \text { years and } 17.1 \% \text { of those aged } 60-69 \text { years reported } \\
\text { using a condom at the most recent sexual event in the past year; lower proportions } \\
\text { were reported by those aged } 70 \text { years and older. }\end{array}$ \\
\hline $\begin{array}{l}\text { Jacobs et al, } \\
(2013)^{38}\end{array}$ & $\begin{array}{l}\text { Community-based } \\
\text { sample of HIV- } \\
\text { negative men who } \\
\text { have sex with men, } \\
\text { aged } 40-81 \text { years, } \\
\mathrm{N}=420\end{array}$ & $\begin{array}{l}\text { Cross-sectional } \\
\text { survey }\end{array}$ & $\begin{array}{l}\text { About a third of the men who reported recent receptive anal intercourse, and about } \\
40 \% \text { of those who reported engaging in insertive anal intercourse, did not use a condom } \\
\text { in the last } 6 \text { months. The majority had multiple partners, and one-third had met a } \\
\text { new partner in the past } 6 \text { months. Two noteworthy findings: men aged } 40-59 \text { years } \\
\text { were more likely to engage in unprotected insertive anal intercourse than their older } \\
\text { counterparts (aged } 60 \text { years and older), and men who discussed their HIV serostatus } \\
\text { with partners were more likely to use condoms than those who did not. }\end{array}$ \\
\hline
\end{tabular}

putting women at increased risk regardless of age. In addition, immune changes in the cervix of healthy postmenopausal women may increase their risk of becoming HIV-infected, an intriguing possibility that remains under investigation. ${ }^{29}$ Older women often do not ask male partners about their risk behaviors, ${ }^{26,30}$ thus avoiding potential conflicts with their sexual partners. ${ }^{26}$ Furthermore, their male partners may not disclose their unprotected sex with men or their injection drug use $^{30-32}$ After menopause, when women no longer need to use birth control to prevent unwanted pregnancies, the need to use condoms may not be perceived to be as essential as it was before menopause. ${ }^{33}$

\section{Men who have sex with men}

Numerous surveys have generated findings about HIV incidence and risk factors for unsafe sex among older MSM. ${ }^{34-39}$
MSM make up about $2 \%$ of the US population but accounted for $59 \%$ of new HIV infections in $2009 .{ }^{40}$ Sexual risk behaviors among MSM may decline with age. ${ }^{41,42}$ The CDC reports a relatively modest incidence (new infections) among MSM aged 55 years or older $(4 \%, 3 \%, 4 \%$, and $4 \%$ of incident infections among MSM in the United States in 2007, 2008, 2009, and 2010, respectively). ${ }^{43}$ However, because MSM are often infected earlier in life, the prevalence of HIV infections in older MSM ( $\geq 50$ years) was as high as $25 \%$ in 21 US cities in $2008 .{ }^{44}$ The high prevalence of HIV among MSM may result from an earlier sexual debut, longer cumulative lifetime periods of new partner acquisition, and more concurrent partnerships, among MSM compared with men who have sex with women. ${ }^{40}$

Several investigators have studied correlates of unsafe sexual behaviors among MSM. A study of sexual behavior 
in midlife and older HIV-negative MSM (N=420) found that erection difficulties, practicing safe sex only with outside partners (ie, not with one's primary partner), and recreational drug use were associated with unprotected receptive anal intercourse. Younger age, not telling partners about one's HIV status, finding partners in backrooms or sex clubs, and erection difficulties were associated with unprotected insertive anal intercourse. ${ }^{38}$ Similar to studies of younger MSM, ${ }^{35,39}$ studies focusing on older MSM have implicated substance use, and prominently alcohol, as a risk factor for unprotected anal intercourse..$^{45,46}$ This risk may be more elevated when erectile dysfunction medications are combined with recreational drugs, and especially with "poppers," a slang term given to alkyl nitrites, a group of substances inhaled for recreational purposes. ${ }^{36,37}$ Some studies have examined the sexual practices of MSM who access Web sites that connect MSM seeking sex with men. MSM seeking partners through these sites may disproportionately engage in risky sexual behaviors, including unprotected anal intercourse. ${ }^{47-51}$

\section{Substance use and high-risk sexual behaviors}

Substance use among older American adults has increased in recent years. ${ }^{34}$ The growing number of older Americans and their increased life expectancy have contributed to a steadily rising number of older adults with a substance use disorder. ${ }^{52-55}$ Unsurprisingly, the number of older adults seeking substance abuse treatment has increased. ${ }^{56}$ Among US adults aged 50 years and older, about $60 \%$ used alcohol in the past year, and $5 \%$ of men and $1.4 \%$ of women met criteria for an alcohol use disorder, 3\% used illicit drugs, and 1\%-2\% used prescription drugs for nonmedical purposes. ${ }^{54}$ Using population-based data, Han et al estimated that the number of Americans aged 50 years or older with a substance use disorder is projected to double from 2.8 million (annual average) in 2002-2006 to 5.7 million in $2020 .{ }^{57}$ Studies of drug and alcohol users have consistently shown that individuals with a substance use disorder are more likely to engage in high-risk sexual behaviors than nondrug users. ${ }^{58}$ Injection drug users are at high risk of becoming HIV-infected regardless of age. The injection drug user population in the United States is aging. Using data from the National Household Survey on Drug Abuse, Armstrong estimated that from 1979 through 2002, the mean age of survey participants who ever injected drugs increased from 26 to 42 years. ${ }^{59}$ As they age, injection drug users experience increases in the prevalence of HIV infection; ${ }^{60}$ they are often diagnosed with multiple illnesses, including non-AIDS-defining chronic conditions. ${ }^{61,62}$ Noninjection drug users are also at increased risk of becoming HIV-infected and infect others through unprotected sex. The association between crack cocaine use and heightened sexual transmission risk is well documented, ${ }^{63}$ and both alcohol and illicit substances are often associated with sexual risk behaviors among older Americans. ${ }^{34,64,65}$

\section{HIV-infected older adults}

HIV-infected older Americans often engage in high-risk sexual behaviors (Table 2) ${ }^{66-68}$ Negative mood states and perceived HIV stigma were correlates of inconsistent condom use among urban sexually active HIV-positive adults aged 45 years and older. ${ }^{66}$ In a study of HIV-positive depressed adults in three US metropolitan areas, among those sexually active, heterosexual men were more likely to report regular condom use (53\%) compared with MSM (23\%) and women (13\%).

There are differences in the timing of diagnosis and in the response to antiretroviral therapy in older adults compared with their younger counterparts. Older individuals may be diagnosed late in the course of disease. ${ }^{17}$ Using data from the North American Cohort Collaboration on Research and Design, Althoff et al ${ }^{69}$ reported that the proportion of individuals aged 50 years and older first presenting for care (among all individuals aged 18 years and older) increased from $17 \%$ in 1997 to $27 \%$ in 2007 ; that CD4 counts at first presentation for HIV care in the United States and Canada among those aged 50 years and older was consistently lower compared with those of younger adults ( $<50$ years), with counts of 266 cells $/ \mathrm{mm}^{3}$ and 336 cells $/ \mathrm{mm}^{3}$, among older and younger participants, respectively, in $2007^{69}$ (low CD4 counts are indicative of a compromised immune system and reflect advanced disease); and that the proportion of individuals who had an AIDS-defining diagnosis at or shortly before the first CD 4 count was highest among older individuals ( $<50$ years, $10 \%$; $\geq 50$ years, $13 \% ; P<0.01){ }^{69}$

\section{Discussion}

American adults are living longer. Although the likelihood of having a steady sexual partner declines with age, and more so among women than among men, ${ }^{4}$ many older Americans remain sexually active in their later years. The availability of medications to treat erectile dysfunction has prolonged the sexual activity of older men and their sexual partners. Although MSM are at highest risk of becoming infected, an increasing number of heterosexual older adults (including women and minority groups) become HIVinfected in middle age and late life. Nevertheless, studies focusing on this age group are relatively sparse. 
This review of the literature found a low prevalence of condom use by older Americans, with about $20 \%$ of men and $24 \%$ of women aged $50+$ years who are not in a long-term relationship with only one partner reporting condom use during the last sexual event. ${ }^{1}$ Older heterosexual adults tend to perceive young people and sexual minority groups (eg, MSM) as being at risk for HIV infection, and they may underestimate their own HIV risk. Thus, their perception of risk may explain in part the low prevalence of condom use. ${ }^{23,70}$ Physicians' perception of sexual risk in older patients may also play a role, leading physicians to ask less frequently about sexual behavior and recommend HIV testing less often when dealing with older compared with younger patients. ${ }^{24,30}$ Thus, older individuals are often diagnosed late, when the disease is more advanced than among newly diagnosed young adults.

\section{Recommendations}

First, there is a need to tailor HIV prevention efforts targeting older adults, consisting of brief interventions targeting at-risk or high-risk older adults, as well as educational programs targeting their health providers. These efforts could include prevention trials specifically targeting older adults as a way of dealing with the discomfort many older adults feel when discussing sexual risk behaviors in the presence of young people. In addition, testing older adults for HIV might lead to earlier diagnosis and follows CDC recommendations advocating routine voluntary HIV screening. ${ }^{71}$

Second, as older adults often see their primary care doctors at least annually, and health care settings are ideal for low-cost psychoeducational interventions, opportunities to intervene in these settings abound. These interventions may include providing written psychoeducational materials, similar to the pamphlets targeting diabetes care or hypertension that patients often read while in physicians' waiting rooms, thus doing away with AIDS exceptionalism by dealing with it as clinical providers deal with other illnesses. ${ }^{72}$

Third, as older individuals are likely to engage in unprotected sex when under the influence of alcohol or recreational drugs (as do their younger counterparts), clinicians should inquire about alcohol and drug use in this age group, and specifically about use preceding or during sexual activity.

Fourth, clinicians need pay special attention to recently divorced or widowed older women who are interested in new relationships, as they may not be aware of their vulnerability, and they should be mindful of the heightened vulnerability of minority women. ${ }^{30}$

Last, prevention efforts should target older MSM separately, as they may not feel comfortable sharing their concerns with older heterosexual adults or with younger MSM. Because the prevalence of HIV infection is high among older MSM, condom use is an essential tool to prevent transmission of the virus from HIV-positive to HIV-negative MSM.

\section{Acknowledgment}

This work is made possible by research support from the US National Institutes of Health (R33DA027503, R01MD007658, R01DA019623, and R01DA019901).

\section{Disclosure}

The authors report no conflicts of interest in this work.

\section{References}

1. Schick V, Herbenick D, Reece M, et al. Sexual behaviors, condom use, and sexual health of Americans over 50: implications for sexual health promotion for older adults. J Sex Med. 2010;7(Suppl 5):315-329.

2. Mahy M, Autenrieth CS, Stanecki K, Wynd S. Increasing trends in HIV prevalence among people aged 50 years and older: evidence from estimates and survey data. AIDS. 2014;28(Suppl 4):S453-S459.

3. Laumann EO, Waite LJ. Sexual dysfunction among older adults: prevalence and risk factors from a nationally representative US probability sample of men and women 57-85 years of age. J Sex Med. 2008;5(10):2300-2311.

4. Lindau ST, Schumm LP, Laumann EO, Levinson W, O’Muircheartaigh CA, Waite LJ. A study of sexuality and health among older adults in the United States. N Engl J Med. 2007;357(8):762-774.

5. Lindau ST, Gavrilova N. Sex, health, and years of sexually active life gained due to good health: evidence from two US population based cross sectional surveys of ageing. BMJ. 2010;340(mar09 2):c810.

6. Centers for Disease Control and Prevention. HIV Surveillance Report, 2011; vol 23. Atlanta, GA: Centers for Disease Control and Prevention; 2013. Available from: http://www.cdc.gov/hiv/library/reports/surveillance/2011/ surveillance_Report_vol_23.html. Accessed January 31, 2015.

7. Centers for Disease Control and Prevention. HIV among older Americans. Atlanta, GA: Centers for Disease Control and Prevention; 2013. Available from: http://www.cdc.gov/hiv/pdf/library_factsheet_ HIV_\%20AmongOlderAmericans.pdf. Accessed April 10, 2015.

8. Centers for Disease Control and Prevention. Diagnoses of HIV infection among adults aged 50 years and older in the United States and dependent areas, 2007-2010. HIV Surveillance Supplemental Report 2013. Atlanta, GA: Centers for Disease Control and Prevention; 2013. Available from: http://www.cdc.gov/hiv/pdf/statistics_2010_HIV_Surveillance_Report_vol_18_no_3.pdf. Accessed October 27, 2014.

9. Linley L, Prejean J, An Q, Chen M, Hall HI. Racial/ethnic disparities in HIV diagnoses among persons aged 50 years and older in 37 US States, 2005-2008. Am J Public Health . 2012;102(8):1527-1534.

10. Davis DH, Smith R, Brown A, Rice B, Yin Z, Delpech V. Early diagnosis and treatment of HIV infection: magnitude of benefit on short-term mortality is greatest in older adults. Age Ageing. 2013;42(4): 520-526.

11. Campsmith ML, Rhodes PH, Hall HI, Green TA. Undiagnosed HIV prevalence among adults and adolescents in the United States at the end of 2006. [Erratum appears in J Acquir Immune Defic Syndr. 2010 May 1;54(1):112]. J Acquir Immune Defic Syndr. 2010;53(5):619-624.

12. Centers for Disease Control and Prevention (CDC). HIV prevalence estimates - United States, 2006. MMWR Morb Mortal Wkly Rep. 2008;57(39):1073-1076.

13. Hall HI, Byers RH, Ling Q, Espinoza L. Racial/ethnic and age disparities in HIV prevalence and disease progression among men who have sex with men in the United States. Am J Public Health. 2007;97(6): 1060-1066. 
14. Herbst JH, Jacobs ED, Finlayson TJ, McKleroy VS, Neumann MS, Crepaz N; HIV/AIDS Prevention Research Synthesis Team. Estimating HIV prevalence and risk behaviors of transgender persons in the United States: a systematic review. AIDS Behav. 2008;12(1):1-17.

15. Prejean J, Song R, Hernandez A, et al; HIV Incidence Surveillance Group. Estimated HIV incidence in the United States, 2006-2009. PLoS ONE. 2011;6(8):e17502.

16. Centers for Disease Control and Prevention. HIV Surveillance Report, 2012; vol 24. Atlanta, GA: Centers for Disease Control and Prevention; 2014. Available from: http://www.cdc.gov/hiv/library/ reports/surveillance/. Accessed January 31, 2015.

17. Brooks JT, Buchacz K, Gebo KA, Mermin J. HIV infection and older Americans: the public health perspective. Am J Public Health. 2012;102(8):1516-1526.

18. Nachega JB, Hsu AJ, Uthman OA, Spinewine A, Pham PA. Antiretroviral therapy adherence and drug-drug interactions in the aging HIV population. AIDS. 2012;26(Suppl 1):S39-S53.

19. Rickabaugh TM, Kilpatrick RD, Hultin LE, et al. The dual impact of HIV-1 infection and aging on naive CD4 T-cells: additive and distinct patterns of impairment. PLOS ONE. 2011;6(1):e16459.

20. Deeken JF, Tjen-A-Looi A, Rudek MA, et al. The rising challenge of non-AIDS-defining cancers in HIV-infected patients. Clin Infect Dis. 2012;55(9):1228-1235.

21. Rebeiro P, Althoff KN, Buchacz K, et al; North American AIDS Cohort Collaboration on Research and Design. Retention among North American HIV-infected persons in clinical care, 2000-2008. J Acquir Immune Defic Syndr. 2013;62(3):356-362.

22. Cooperman NA, Arnsten JH, Klein RS. Current sexual activity and risky sexual behavior in older men with or at risk for HIV infection. AIDS Educ Prev. 2007;19(4):321-333.

23. Levy JA, Ory MG, Crystal S. HIV/AIDS interventions for midlife and older adults: current status and challenges. J Acquir Immune Defic Syndr. 2003;33(Suppl 2):S59-S67.

24. Loeb DF, Lee RS, Binswanger IA, Ellison MC, Aagaard EM. Patient, resident physician, and visit factors associated with documentation of sexual history in the outpatient setting. J Gen Intern Med. 2011;26(8): 887-893.

25. Durvasula R. HIV/AIDS in older women: unique challenges, unmet needs. Behav Med. 2014;40(3):85-98.

26. Jacobs RJ, Thomlison B. Self-silencing and age as risk factors for sexually acquired HIV in midlife and older women. J Aging Health. 2009;21(1):102-128.

27. Akers AY, Bernstein L, Doyle J, Corbie-Smith G. Older women and HIV testing: examining the relationship between HIV testing history, age, and lifetime HIV risk behaviors. Sex Transm Dis. 2008;35(4): 420-423.

28. Padian NS, Shiboski SC, Glass SO, Vittinghoff E. Heterosexual transmission of human immunodeficiency virus (HIV) in northern California: results from a ten-year study. Am J Epidemiol. 1997;146(4): 350-357.

29. Meditz AL, Moreau KL, MaWhinney S, et al. CCR5 expression is elevated on endocervical CD4+ T cells in healthy postmenopausal women. J Acquir Immune Defic Syndr. 2012;59(3):221-228.

30. Beaulaurier R, Fortuna K, Lind D, Emlet CA. Attitudes and stereotypes regarding older women and HIV risk. $J$ Women Aging. 2014;26(4): 351-368.

31. Montgomery JP, Mokotoff ED, Gentry AC, Blair JM. The extent of bisexual behaviour in HIV-infected men and implications for transmission to their female sex partners. [Erratum appears in AIDS Care. 2004 Oct;16(7):923]. AIDS Care. 2003;15(6):829-837.

32. Wolitski RJ, Fenton KA. Sexual health, HIV, and sexually transmitted infections among gay, bisexual, and other men who have sex with men in the United States. AIDS Behav. 2011;15(Suppl 1):S9-S17.

33. Lindau ST, Leitsch SA, Lundberg KL, Jerome J. Older women's attitudes, behavior, and communication about sex and HIV: a communitybased study. J Womens Health (Larchmt). 2006;15(6):747-753.

34. Brennan-Ing M, Porter KE, Seidel L, Karpiak SE. Substance use and sexual risk differences among older bisexual and gay men with HIV. Behav Med. 2014;40(3):108-115.
35. Drumright LN, Strathdee SA, Little SJ, et al. Unprotected anal intercourse and substance use before and after HIV diagnosis among recently HIV-infected men who have sex with men. Sex Transm Dis. 2007;34(6):401-407.

36. Goltz HH, Coon DW, Catania JA, Latini DM. A pilot study of HIV/ STI risk among men having sex with men using erectile dysfunction medications: challenges and opportunities for sexual medicine physicians. J Sex Med. 2012;9(12):3189-3197.

37. Ompad DC, Kingdon M, Kupprat S, Halkitis SN, Storholm ED, Halkitis PN. Smoking and HIV-related health issues among older HIVpositive gay, bisexual, and other men who have sex with men. Behav Med. 2014;40(3):99-107.

38. Jacobs RJ, Kane MN, Ownby RL. Condom use, disclosure, and risk for unprotected sex in HIV-negative midlife and older men who have sex with men. Am J Men Health. 2013;7(3):186-197.

39. Mayer KH, O'Cleirigh C, Skeer M, et al. Which HIV-infected men who have sex with men in care are engaging in risky sex and acquiring sexually transmitted infections: findings from a Boston community health centre. Sex Transm Infect. 2010;86(1):66-70.

40. Glick SN, Morris M, Foxman B, et al. A comparison of sexual behavior patterns among men who have sex with men and heterosexual men and women. J Acquir Immune Defic Syndr. 2012;60(1):83-90.

41. Dolcini MM, Catania JA, Stall RD, Pollack L. The HIV epidemic among older men who have sex with men. J Acquir Immune Defic Syndr. 2003;33(Suppl 2):S115-S121.

42. Jacobs RJ, Fernandez MI, Ownby RL, Bowen GS, Hardigan PC, Kane MN. Factors associated with risk for unprotected receptive and insertive anal intercourse in men aged 40 and older who have sex with men. AIDS Care. 2010;22(10):1204-1211.

43. Centers for Disease Control and Prevention. Estimated HIV incidence among adults and adolescents in the United States, 2007-2010. Atlanta, GA: Centers for Disease Control and Prevention; 2012. Available from: http://www.cdc.gov/hiv/pdf/statistics_hssr_vol_17_no_4.pdf. Accessed March 27, 2015.

44. Centers for Disease Control and Prevention (CDC). Prevalence and awareness of HIV infection among men who have sex with men - 21 cities, United States, 2008. MMWR Morb Mortal Wkly Rep. 2010; 59(37):1201-1207.

45. King KM, Nguyen HV, Kosterman R, Bailey JA, Hawkins JD. Cooccurrence of sexual risk behaviors and substance use across emerging adulthood: evidence for state- and trait-level associations. Addiction. 2012;107(7):1288-1296.

46. McCarty-Caplan D, Jantz I, Swartz J. MSM and drug use: A latent class analysis of drug use and related sexual risk behaviors. AIDS Behav. 2014;18(7):1339-1351.

47. Bolding G, Davis M, Sherr L, Hart G, Elford J. Use of gay Internet sites and views about online health promotion among men who have sex with men. AIDS Care. 2004;16(8):993-1001.

48. Bolding G, Davis M, Hart G, Sherr L, Elford J. Gay men who look for sex on the Internet: is there more HIV/STI risk with online partners? AIDS. 2005;19(9):961-968.

49. McFarlane M, Bull SS, Rietmeijer CA. The Internet as a newly emerging risk environment for sexually transmitted diseases. JAMA. 2000;284(4):443-446.

50. Ogilvie GS, Taylor DL, Trussler T, et al. Seeking sexual partners on the internet: a marker for risky sexual behaviour in men who have sex with men. Can J Public Health. 2008;99(3):185-188.

51. Sowell RL, Phillips KD. Men seeking sex on an intergenerational gay Internet website: an exploratory study. Public Health Rep. 2010;125(Suppl 1):21-28.

52. Lofwall MR, Brooner RK, Bigelow GE, Kindbom K, Strain EC. Characteristics of older opioid maintenance patients. $J$ Subst Abuse Treat. 2005;28(3):265-272.

53. Rosen D, Smith ML, Reynolds CF III. The prevalence of mental and physical health disorders among older methadone patients. Am J Geriatr Psychiatry. 2008;16(6):488-497.

54. Wu LT, Blazer DG. Substance use disorders and psychiatric comorbidity in mid and later life: a review. Int J Epidemiol. 2014;43(2):304-317. 
55. Wu LT, Blazer DG. Illicit and nonmedical drug use among older adults: a review. J Aging Health. 2011;23(3):481-504.

56. Arndt S, Gunter TD, Acion L. Older admissions to substance abuse treatment in 2001. Am J Geriatr Psychiatry. 2005;13(5):385-392.

57. Han B, Gfroerer JC, Colliver JD, Penne MA. Substance use disorder among older adults in the United States in 2020. Addiction. 2009; 104(1):88-96.

58. Meader N, Semaan S, Halton M, et al. An international systematic review and meta-analysis of multisession psychosocial interventions compared with educational or minimal interventions on the HIV sex risk behaviors of people who use drugs. AIDS Behav. 2013;17(6):1963-1978.

59. Armstrong GL. Injection drug users in the United States, 1979-2002: an aging population. Arch Intern Med. 2007;167(2):166-173.

60. Broz D, Pham H, Spiller M, et al. Prevalence of HIV infection and risk behaviors among younger and older injecting drug users in the United States, 2009. AIDS Behav. 2014;18(Suppl 3):284-296.

61. Drummond MB, Merlo CA, Astemborski J, et al. The effect of HIV infection on longitudinal lung function decline among IDUs: a prospective cohort. AIDS. 2013;27(8):1303-1311.

62. Salter ML, Lau B, Go VF, Mehta SH, Kirk GD. HIV infection, immune suppression, and uncontrolled viremia are associated with increased multimorbidity among aging injection drug users. Clin Infect Dis. 2011;53(12):1256-1264.

63. Khan MR, Berger A, Hemberg J, O'Neill A, Dyer TP, Smyrk K. Non-injection and injection drug use and STI/HIV risk in the United States: the degree to which sexual risk behaviors versus sex with an STI-infected partner account for infection transmission among drug users. AIDS Behav. 2013;17(3):1185-1194.

64. Heath J, Lanoye A, Maisto SA. The role of alcohol and substance use in risky sexual behavior among older men who have sex with men: a review and critique of the current literature. AIDS Behav. 2012;16(3): $578-589$.
65. Johnson SD, Striley C, Cottler LB. Comorbid substance use and HIV risk in older African American drug users. JAging Health. 2007;19(4): 646-658.

66. Illa L, Brickman A, Saint-Jean G, et al. Sexual risk behaviors in late middle age and older HIV seropositive adults. AIDS Behav. 2008;12(6): 935-942.

67. Lovejoy TI, Heckman TG, Sikkema KJ, et al. Patterns and correlates of sexual activity and condom use behavior in persons 50-plus years of age living with HIV/AIDS. AIDS Behav. 2008;12(6):943-956.

68. Onen NF, Shacham E, Stamm KE, Overton ET. Comparisons of sexual behaviors and STD prevalence among older and younger individuals with HIV infection. AIDS Care. 2010;22(6):711-717.

69. Althoff KN, Gebo KA, Gange SJ, et al; North American AIDS Cohort Collaboration on Research and Design. CD4 count at presentation for HIV care in the United States and Canada: are those over 50 years more likely to have a delayed presentation? AIDS Res Ther. 2010;7(1):45.

70. Savasta AM. HIV: associated transmission risks in older adults an integrative review of the literature. $J$ Assoc Nurses AIDS Care. 2004;15(1):50-59.

71. Branson BM, Handsfield HH, Lampe MA, et al; Centers for Disease Control and Prevention (CDC). Revised recommendations for HIV testing of adults, adolescents, and pregnant women in health-care settings. MMWR Recomm Rep. 2006;55(RR-14):1-17.

72. Bayer R, Fairchild AL. Changing the paradigm for HIV testing - the end of exceptionalism. $N$ Engl J Med. 2006;355(7):647-649.

73. Centers for Disease Control and Prevention. HIV Among Older Americans. Atlanta, GA: Centers for Disease Control and Prevention; 2013. Available from: http://www.cdc.gov/hiv/risk/age/olderamericans/. Accessed: October 15, 2014.
Substance Abuse and Rehabilitation

\section{Publish your work in this journal}

Substance Abuse and Rehabilitation is an international, peer-reviewed, open access journal publishing original research, case reports, editorials, reviews and commentaries on all areas of addiction and substance abuse and options for treatment and rehabilitation. The manuscript management system is completely online and includes a very quick and fair

\section{Dovepress}

peer-review system. Visit http://www.dovepress.com/testimonials.php to read real quotes from published authors. 